CONTENTIOUS ISSUES ARISING FROM PAYMENTS MADE IN FULL AND FINAL

SETTLEMENT

ISSN 1727-3781

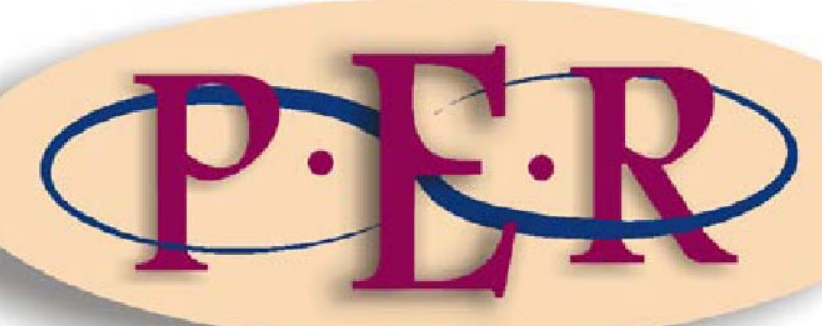

2008 VOLUME 11 NO 4 


\section{CONTENTIOUS ISSUES ARISING FROM PAYMENTS MADE IN FULL AND FINAL SETTLEMENT}

\section{R Ismail*}

\section{Introduction}

Payments made in full and final settlement have on several occasions presented interpretative difficulties for our judiciary, ${ }^{1}$ as will become apparent from this case discussion. ${ }^{2}$ The Supreme Court of Appeal $^{3}$ reversed the judgments of the trial court and the appeal court (full bench of the Cape Provincial Division) which were in favour of the creditor. ${ }^{4}$ In such cases, the essential enquiry is whether an agreement of compromise exists. A transactio or compromise (in the form of a legal agreement) exists where the relevant parties agree to settle previously disputed or uncertain obligations. ${ }^{5}$ Like any other agreement, a compromise is based on the contractual rules of offer and acceptance. $^{6}$

* BA (Law), LLB (Natal), LLM (UKZN), Senior Lecturer in Private Law, University of South Africa.

1 Several judgments dealing with this problematic aspect of the law of contract have been reversed on appeal, see eg, Harris $v$ Pieters 1920 AD 644; Van Breukelen $v$ Van Breukelen 19662 SA 285 (A); Blackie Swart Argitekte $v$ Van Heerden 19861 SA 238 (A); Patterson Exhibitions v Knights Advertising \& Marketing 19913 SA 523 (A); Kei Brick \& Tile v AM Construction 19961 SA 150 (E); and RCG Trade \& Finance v Garstang 2002 JDR $0451(\mathrm{~W})$.

2 This discussion is based on the case, Be Bop A Lula Manufacturing \& Printing $v$ Kingtex Marketing 20083 SA 327 (SCA).

3 Hereafter the SCA.

4 Hereafter the CPD.

5 Karson v Minister of Public Works 19961 SA 887 (E) 893F-H; Christie Law of Contract 455-456; and Sharrock Business Transactions Law 221-222.

$6 \quad$ See eg, Patterson Exhibitions v Knights Advertising \& Marketing 19913 SA 523 (A) 528; Absa Bank v Van De Vyver 20024 SA 397 (SCA) 402A-F; Christie, supra n 5, 459; Sharrock, supra n 5, 221; and Zeffertt 1972 SALJ 38. These references are consistent with the case under discussion, Be Bop A Lula Manufacturing \& Printing $v$ Kingtex Marketing 20083 SA 327 (SCA), and overrides the decision taken in Louw v Granowsky 19602 SA 637 (SWA) 641E-G that there is no need for the debtor to prove that a contract of compromise exists, if the creditor retains and appropriates the payment made in full and final settlement. 
The focus of this discussion relates to the recent SCA judgment in Be Bop $A$ Lula Manufacturing \& Printing CC $v$ Kingtex Marketing (Pty) Ltd. ${ }^{7}$ The first material enquiry in this case wherein the debtor delivered the cheque payment to the creditor (in full and final settlement of the account), is whether:

1. an intended offer of compromise exists; or

2. did the debtor merely ${ }^{8}$ intend to make payment towards an admitted liability.

Critical to the above enquiry is the fact that the debtor delivered the precise amount it believed it owed to the creditor. In this specific context, ${ }^{9}$ it was reasoned by the court in Karson $v$ Minister of Public Works ${ }^{10}$ that it is easier to find that a debtor made payment towards an admitted liability when a debtor delivers the precise amount he believes he owes the creditor. However, such a conclusion can never be arrived at easily, since in such circumstances an intended offer of compromise could exist. ${ }^{11}$ If an offer of compromise exists, the second stage of the enquiry is whether or not acceptance of the said offer has been effected, and whilst this enquiry is not the material focus of this case discussion, it will be addressed briefly.

7 Be Bop A Lula Manufacturing \& Printing v Kingtex Marketing 20083 SA 327 (SCA), (hereafter the Be Bop (SCA) case).

8 The importance of this word is expressed in 2.2 of the text.

9 For examples where the debtor delivers the precise amount that he/it believed was owing to the creditor, see eg, Harris v Pieters 1920 AD 644; Tractor \& Excavator Spares $v$ Lucas J Botha 19662 SA 740 (T); Andy's Electrical v Laurie Sykes 19793 SA 341 (N); Kei Brick \& Tile $v$ AM Construction 19961 SA 150 (E); Karson v Minister of Public Works 1996 (1)SA 887 (E); and the Be Pop (SCA) case.

10 See Karson v Minister of Public Works 19961 SA 887 (ECD) 895G-H, (hereafter the Karson case).

11 For cases that illustrate the point that delivering payment for the precise amount the debtor believes he owes the creditor (in full and final settlement) does not preclude the prospect that an offer of compromise could exist, see eg, Van Breukelen v Van Breukelen 19662 SA 285 (A) 290D; Tractor \& Excavator Spares v Lucas J Botha 19662 SA 740 (T); and Andy's Electrical v Laurie Sykes 19793 SA 341(N). 


\section{Legal principles (background)}

\subsection{Consequences of an offer of compromise in comparison with payment of an admitted liability}

It is significant to note the consequences that follow for both debtor and creditor from the outcome of whether or not an offer of compromise exists, in contrast with a mere payment towards the debtor's admitted liability.

1. If the debtor's payment constitutes an offer of compromise (referred to as animo contrahendi), ${ }^{12}$ which the creditor accepts, the creditor generally cannot make any further claim against the debtor. ${ }^{13}$ It does not help the creditor to accept the offer of compromise "without prejudice" or to add terms and conditions to the debtors' offer of compromise, ${ }^{14}$ the reason being that the offer of compromise (made in full and final settlement) is generally accepted based on the implied (if not express) condition that the creditor abandons the balance of his claim. ${ }^{15}$

2. If the amount delivered merely represents payment of the debtor's admitted liability (referred to as animo solvendi) ${ }^{16}$ the creditor can retain and deposit the monies received and thereafter sue the debtor

12 See Harris v Pieters 1920 AD 644, at 654-655; and Be Bop A Lula Manufacturing \& Printing $v$ Kingtex Marketing 20066 SA 379 (C) 392H-I. In the latter case it should be noted that the citation is different from the Be Bop (SCA) case.

13 See Odendaal v Du Plessis 1918 AD 470, 475-478; Neville v Plasket 1935 TPD 115, 120; Turgin v Atlantic Clothing Manufacturers 19543 SA 527 (T) 532G-H; Van Breukelen v Van Breukelen 19662 SA 285 (A); Tractor \& Excavator Spares v Lucas J Botha 19662 SA 740 (T) 743C-E; Cecil Jacobs v Mcleod \& Sons 19664 SA 41 (N) 48H-51A; Andy's Electrical v Laurie Sykes 19793 SA 341 (N) 343A-C; Absa Bank v Van De Vyver 20024 SA 397 (SCA) 402B-F; RCG Trade \& Finance v Garstang 2002 JDR 0451 (W) 30; Kerr Principles of Law of Contract 536; Christie, supra n 5, 460; Sharrock, supra n 5, 223 and Zeffertt, supra $\mathrm{n}$ 6, 41. However, for limited circumstances when the creditor may retain the debtor's payment (that is accompanied by the offer of compromise) and still legitimately claim the balance owing, see the cases referred to in (n 105) and Burt $v$ National Bank of South Africa 1921 AD 59. See also McLennan 2002 SALJ 686, where the author warns that the banking of the cheque by the creditor will not always provide conclusive proof of acceptance of an offer of compromise.

14 Andy's Electrical v Laurie Sykes 19793 SA 341 (N) 343A-B.

15 See in general, the references in $\mathrm{n} 13$.

16 Harris v Pieters 1920 AD 644, at 654-655; and Be Bop A Lula Manufacturing \& Printing v Kingtex Marketing 20066 SA 379 (C) 392H-I. 
for the balance of his claim. ${ }^{17}$ This is the case irrespective of whether the debtor expressed to the creditor that such payment is made in full and final settlement of the claim. ${ }^{18}$ In this context, the creditor can legitimately regard these words as being pro non scripto, $^{19}$ the reason being that the debtor cannot include the condition that the creditor's retention of the payment of the admitted liability finally settles the balance of the creditor's claim as well, if such a condition was not intended in the contract between the debtor and the creditor, or implied in law. ${ }^{20}$

Therefore, whether the payment constitutes an intended offer of compromise or mere payment towards an admitted liability is crucial, due to the consequences that flow from this enquiry. Furthermore, where there is doubt or uncertainty whether or not the debtor establishes that an offer of compromise exists, the contra proferentem rule will apply. In terms of this rule the construction unfavourable to the debtor will prevail, as he had the power to make his intention clear when he made the payment. ${ }^{21}$

\subsection{Admitting liability for a specific amount and delivering payment accordingly}

In the Be Bop (SCA) case, the debtor admitted liability for a specific amount and delivered payment accordingly (in full and final settlement) to the creditor.

17 See eg, Harris v Pieters 1920 AD 644, at 649-650; Karson v Minister of Public Works 1996 1 SA 887 (E) 895F-I; Kei Brick \& Tile v AM Construction 19961 SA 150 (E) 158A-B; Absa Bank v Van De Vyver 20024 SA 397 (SCA) 404A-B; Kerr, supra n 13, 536; and Christie, supra n 5, 458; Zeffertt, supra n 6, 41-42.

18 See eg, Harris v Pieters 1920 AD 644, at 649-651; and Cecil Jacobs v Mcleod \& Sons 19664 SA 41 (N) 46D-H.

19 See Harris v Pieters 1920 AD 644, at 649; Cecil Jacobs v Macleod \& Sons 19664 SA 41 (N) 46G-H; and Zeffertt, supra n 6, 41-42.

20 See Harris v Pieters 1920 AD 644, at 650; and Cecil Jacobs v Mcleod \& Sons 19664 SA 41 (N) 46F-G.

21 See eg, Harris v Pieters 1920 AD 644, at 655; Cecil Jacobs v Mcleod \& Sons 19664 SA 41 (N) 47A-B; Andy's Electrical v Laurie Sykes 19793 SA 341 (N) 345A-B; Karson v Minister of Public Works 19961 SA 887 (E) 896C-D; Absa Bank v Van De Vyver 20024 SA 397 (SCA) 405C-D; Christie, supra n 5, 457-459; and Sharrock, supra n 5, 222. In Kei Brick \& Tile v AM Construction 19961 SA 150 (E) the majority judgment reasoned that the debtor's words, "ter vereffening van die rekening" (par 152E) meant "in payment of the account", which did not mean "in full settlement" (par 157C-D), and in the context of the debtor's letter addressed to the creditor it was interpreted contra proferentem (par 157C$\mathrm{G)}$. 
Before the facts of the Be Bop (SCA) case are set out, it is relevant to consider the approach previously taken by our judiciary, to assess whether an offer of compromise exists or if this is a mere payment of an admitted liability, in the context dealt with in this section of this article.

In Andy's Electrical v Laurie Sykes (Pty) $L t d^{22}$ and Tractor \& Excavator Spares (Pty) Ltd $v$ Lucas $\mathrm{J}$ Botha (Pty) Ltd, ${ }^{23}$ the debtor (in both cases) admitted liability for a specific amount and delivered this amount to the creditor. In both cases, the Natal Provincial Division ${ }^{24}$ and the Transvaal Provincial Division ${ }^{25}$ respectively found that an offer of compromise existed. Both of these cases therefore highlight the point that payment of an admitted debt (for a specific amount believed to be owing by the debtor) can be accompanied by an offer of compromise. This point is justified as there is no bar precluding a person from offering to compromise a claim, where he admits liability for a specific amount and makes payment accordingly. Therefore, in the Andy's Electrical case Didcott $\mathrm{J}$ justifiably criticised judgments that simplistically, "distinguished offers of compromise from payments of admitted debts, as if the one sort of transaction necessarily excluded the other". ${ }^{26}$

However, there are certain dicta (when read in isolation) in some cases which may tend to confuse and incline a reader to think that payment of an admitted debt excludes the possibility that an offer of compromise could nevertheless still exist. $^{27}$ In the Karson case, the amount paid by the debtor represented the precise capital balance, which the debtor conceded to be the extent of his

23 Tractor \& Excavator Spares $v$ Lucas J Botha 19662 SA 740 (T). (Hereafter the Tractor case).

24 Hereafter the NPD.

25 Hereafter the TPD.

26 Par 344B.

27 See eg, the Andy's Electrical case (at par 346A-B) where Didcott J stated that such dicta are contained in Harris $v$ Pieters 1920 AD 644, at 649-650. See the dicta also in Cecil Jacobs $v$ Mcleod \& Sons 19664 SA 41 (N) (at par 46F, 48C-D and 48G-H) which create a similar perception when read in isolation. In the latter case, a material enquiry in the circumstances appears to be whether the debtor admitted the precise extent of his liability in monetary terms and made payment accordingly. These instances could create the perception that if this is the case and the enquiry ends here, it may automatically constitute mere payment of an admitted liability. 
admitted indebtedness. This fact appears to be the overwhelming factor that easily persuaded the court to conclude that payment of an admitted liability was intended, without practically considering whether this admission of liability was nevertheless accompanied by an offer of compromise. ${ }^{28}$ In this context the approach taken in the Karson case is hereby respectfully criticised, and later in this discussion the court's actual finding that mere payment of an admitted debt was intended will be addressed.

In Absa Bank $v$ Van De $V_{y v e{ }^{29}}$ there are also certain dicta that create the perception that payment towards what the debtor believes he owes the creditor may exclude the possibility that an offer of compromise could exist. It was reasoned by the court (in the Absa Bank case) that an offer of compromise could exist even when there is an admission of liability on the part of the debtor. $^{30}$ The ambit of this reasoning is broad enough to include situations that could result in the existence of an offer of compromise when the debtor delivers the precise amount he believes he owes to the creditor. However, the approach of the SCA does not positively create this perception. In the Absa Bank case, the debtor delivered R180 000.00 to the creditor, and the central focus of the SCA (in the entire judgment) was that the "inference from the proved facts cannot demonstrate that R180 000.00 was the extent of the estate's undeniable liability at the relevant time". ${ }^{31}$ As a result, the SCA concluded that an offer of

28 See the Karson case, at par 895G-896A, and at par 895G-H, where it is reasoned that it is easier (emphasis added) to conclude that mere payment of an admitted debt is made, "particularly so where the amount tendered is in respect of an admitted liability (which is here the case, viz the admitted R108 000 of unpaid capital) as, if a debtor delivers to his creditor payment of his admitted liability accompanied by a statement that it is paid in full settlement, the creditor is not bound to accept the payment as such but may retain it". Thereafter (at par 895I-896A) the court reiterates and places "considerable importance" on the fact that that the sum of R108 000 was admitted by the debtor to be owing to the creditor. Following from this line of reasoning, the court then simplistically concludes that payment is made towards an admitted liability (see par 896A). The effect of this reasoning is that the court concluded that payment was made towards an admitted liability simply because the debtor admitted that he was indebted to the creditor in the sum of R108 000.00 and he delivered this payment to the creditor. It has already been pointed out that admitting liability for a certain amount which is consistent with the debtor's payment is not (in isolation) conclusive that an offer of compromise does not exist.

29 See Absa Bank v Van De Vyver 20024 SA 397 (SCA) 405C, 405H-J, 406A-B, and 406I407A. (Hereafter the Absa Bank case).

30 Par 18.

31 See par 21. See also, at par 18, where the SCA referred to the Patterson Exhibition $v$ Knights Advertising \& Marketing 19913 SA 523 (A) case, by highlighting that the debtor in 
compromise was intended by the debtor. ${ }^{32}$ However, the perception created by the SCA is that if the said R180 000.00 demonstrates the debtor's undeniable liability, the conclusion could automatically be that payment was made towards an admitted liability ${ }^{33}$ and not for the purpose of compromising the creditor's claim. It has already been discussed hereinabove that such a conclusion will not automatically follow in these circumstances, as an offer of compromise could still exist. $^{34}$

Contrary to this view, the court in the Be Bop (SCA) case ${ }^{35}$ relied on the reasoning of the SCA in the Absa Bank case ${ }^{36}$ as authority for the principle that admission of liability for a certain amount is no bar to excluding the possibility that an offer of compromise could still exist. However, it is respectfully reiterated that the Absa Bank case did not positively create this perception. Furthermore, the justification of the court in the Be Bop (SCA) case ${ }^{37}$ relies on dicta in the Absa Bank case ${ }^{38}$ that do not directly refer to an admission of liability in a certain or precise amount (on the part of the debtor). Instead these dicta refer to examples wherein all liability is denied, ${ }^{39}$ or where some liability is admitted without admitting how much, ${ }^{40}$ or where some liability is admitted without admitting that the payment offered represented the admitted indebtedness. ${ }^{41}$ In all of these circumstances, especially the latter, it appears

that case did not state that "the payment offered represented the admitted indebtedness", and at par 21 the SCA again reiterated that "[n]o evidence and no calculations serve to show, however, that the sum of R180 000 offered by the respondent in the letter in issue corresponded closely, or even as a rough approximation, to what the overall indebtedness on the two accounts would have been", and at par 22 the SCA reasoned that what the debtor's letter "plainly does not say is that liability in the sum of R180 000 is admitted or that this represents the limit of the estate's indebtedness", and finally at par 25, after stating that the letters addressed by the debtor to the creditor did not show that the sum of R180 000 represented the debtors "view of the estate's indebtedness or that indebtedness in that amount", the court reasoned that an offer of compromise was intended.

32 See par 25.

33 This inference is drawn when consideration is given to the probe of the SCA, as is set out in (n 31) above.

34 See content relating to above (n 22 to $\mathrm{n} 26$ ). Also see the Andy's Electrical case; the Tractor case; and the Van Breukelen case, at 290D.

35 Par 11.

36 Par 15-18 in the Absa Bank case.

37 Par 11.

38 Par 15-18 in the Absa Bank case.

39 Par 15 in the Absa Bank case.

40 Par 18 in the Absa Bank case.

41 Ibid. 
that the court in the Absa Bank case did not refer to the scenario wherein the debtor admits that a specific amount is owing to the creditor. Therefore, it is respectfully submitted that it was not appropriate for the court in the Be Bop (SCA) case to utilise the Absa Bank case to illustrate the principle that "admitted liability in a certain amount is no bar to the proposal being construed as an offer of compromise". ${ }^{42}$ The more appropriate authorities to illustrate this principle are the Tractor case, the Andy's Electrical case and the Van Breukelen $v$ Van Breukelen case. ${ }^{43}$

At times the approach of our judiciary to this issue is a concern, and in this regard it is respectfully submitted that a basic oversight may sometimes be the manner in which the wording of the enquiry is formulated (to establish if an offer of compromise exists). In the Be Bop (CPD) case the enquiry set out was whether the debtor intended "an offer of compromise or as an offer to pay what the debtor believes he owes the creditor". ${ }^{44}$ In the Absa Bank case, a similar enquiry was formulated, "whether the payment made is intended to effect a compromise or pay an admitted liability". ${ }^{45}$ With an enquiry of this nature it seems all too simplistic to exclude the possibility that an offer of compromise exists once the debtor admits that a specific amount is owing to the creditor and he makes payment accordingly. This type of enquiry creates the perception that one transaction (admission of liability for a specific amount accompanied by payment) excludes the other (the possibility that an offer of compromise could nevertheless still exist), which is a perception Didcott $\mathrm{J}$ rejected and warned against in the Andy's Electrical case. ${ }^{46}$

To allow for the debtor to intend an offer of compromise despite also making precise payment towards an admitted debt, it appears that the insertion of the word "merely" (into the judicial enquiry) has the potential to reverse the

42 The Be Bop (SCA) case, par 11.

43 Van Breukelen v Van Breukelen 19662 SA 285 (A) 290D. (Hereafter the Van Breukelen case).

$44 \quad$ Par 42.

45 Par 16.

46 See par 344B; see also the Van Breukelen case, at 290D; and Harris v Pieters 1920 AD 644 , at 649 , where it is reasoned that a compromise could be intended even where liability to the extent of the tender is admitted. 
perception just alluded to. Zeffertt ${ }^{47}$ wisely suggests that the enquiry be "whether an offer of compromise has been made or payment of an amount which the debtor merely ${ }^{48}$ regards as reflecting the extent of his indebtedness". Accordingly, if the debtor wants to make payment towards his precise admitted indebtedness (evidencing admission of liability for a specific amount), and he also intends to compromise the claim, he is not merely doing the former. He is doing more than that. An intended offer of compromise could therefore nevertheless still exist. This observation should serve as an appropriate starting point for our judiciary when presented with disputes of this nature.

There appears to be theoretical consensus that it is not sufficient to preclude the possibility that an offer of compromise may still exist even when payment of a specific amount believed to be owing is delivered by the debtor to the creditor. However, our judiciary have not at times iterated this perception. Against this background, it is necessary to discuss whether the court in the $B e$ Bop (SCA) case gave recognition to this principle.

\section{Facts and decision}

In evaluating the factual evidence in this case, the essential focus of interpretation centred on the written correspondences exchanged between the debtor and the creditor. These correspondences contain the pertinent facts relevant to this discussion, which are as follows:

1. In response to the creditor's claim for R229 846.07, the debtor sent the creditor a written correspondence (dated 19 February 2002)

47 Zeffertt, supra n 6, 48; see also eg, the Karson case at par 895C-D, where reference is made to the word "merely" in the formulated enquiry; the Andy's Electrical case at par 346A where the word "mere" is utilised; Cecil Jacobs v Mcleod \& Sons 19664 SA 41 (N) (at par 46C) where the words "to do more than" have a similar effect to the word "merely"; Kei Brick \& Tile v AM Construction 19961 SA 150 (E) (at par 157E-F), where the word "merely" is utilised; and RCG Trade \& Finance v Garstang 2002 JDR 0451 (W) 24, where it is stated "that they constituted an offer of compromise and not merely the evidence of an intention to pay". Own emphasis. 
advising the creditor that certain garments it delivered were defective, for which a credit request was made, in the sum of R122 649,18.

2. A second letter dated 19 February 2002 was addressed by the debtor to the creditor, described as a 'Final Reconciliation' correspondence, in which the debtor deducted the amount of its credit request (R122 649,18), from the capital amount (R229 846,07) claimed by the creditor, leaving a final balance (according to the debtor) of R107 196,89 (thereby acknowledging the precise amount believed to be owing).

3. On 19 February 2002 the debtor delivered a cheque (dated 28 February 2002) to the creditor for R107 196,89.

4. The said cheque which evidenced the words "full and final settlement of account" on the front of the cheque was paid by the bank on 28 February 2002, after an employee of the creditor (who was following the creditor's banking policy) deposited the cheque (for special clearance) into the creditor's bank account.

5. On 1 March 2002, the creditor (through its attorneys) sent a letter (by fax) to the debtor (dated 1 March 2002) advising the debtor, as follows:

5.1 The creditor disagreed with the debtor's credit request.

5.2 The creditor does not accept the cheque issued by the debtor, as payment in full and final settlement of the account, and if the debtor disagrees it should stop payment on the cheque, otherwise the payment will be placed in the creditor's attorneys trust account, pending the outcome of the dispute.

6. The debtor then addressed a letter to the creditor, (dated 4 March 2002), advising the creditor, that:

6.1 The creditor's letter dated 1 March 2002 was received by it only on 4 March 2002.

6.2 The bank advised it (the debtor) that it was too late to stop payment on the cheque. 
6.3 In the circumstances, by depositing the cheque, the creditor accepted the condition that the cheque payment was made in full and final settlement of the account.

6.4 The deduction of the costs (relating to the credit request) was not a bogus claim.

6.5 Should the matter still be pursued by the creditor, a counterclaim will be forthcoming by the debtor, for a loss of profit incurred by the debtor, because the creditor failed to deliver 20000 T-shirts timeously.

7. The result was that the creditor placed the payment in its attorney's trust account, and at some stage a portion of this amount was appropriated in favour of the creditor.

The court in the Be Bop (SCA) case had to decide two issues. Firstly, whether or not the two letters (dated 19 February 2002) and the cheque payment sent by the debtor to the creditor constituted an offer of compromise. Secondly, if an offer of compromise existed, whether or not the depositing of the cheque into the creditor's bank account, accompanied by the subsequent retention and partial appropriation of a portion of the said cheque payment in favour of the creditor, constituted acceptance of the offer of compromise. On both accounts, the court in the Be Bop (SCA) case reversed the findings of the court in the CPD, by ruling firstly that an offer of compromise existed, and secondly that acceptance of the offer was effected (although it was reasoned that actual consensus may have been absent).

\section{Analysis of the decision that an offer of compromise existed}

It is submitted that this decision made by the court in the Be Bop (SCA) case was correct, for the following reasons:

In the Be Bop (SCA) case, the debtor admitted the precise monetary extent of its indebtedness, and accordingly made payment to the creditor (in full and final 
settlement). This fact itself is not conclusive that an offer of compromise is automatically excluded. ${ }^{49}$ The issue then arises as to whether, despite this fact, the debtor nevertheless intended to compromise the claim. ${ }^{50}$ Given the complex and technical nature of this enquiry, Didcott $\mathrm{J}$ (in the Andy's Electrical case) appropriately reasoned that the objective should be to determine the real purpose of the payment. ${ }^{51}$ In essence, the learned judge summed up the enquiry to be whether the debtor intended to settle the whole claim by paying a particular amount, or whether payment was made with the intention that the rest of the claim remains in issue. ${ }^{52}$ If the real purpose of the payment is to settle the whole dispute, an offer of compromise is intended and "not the mere discharge of an acknowledged liability". ${ }^{53}$ In the Be Bop (SCA) case the facts are similar to the facts in the Andy's Electrical case, as the debtor (after reconstructing the creditor's demand or statement of account) admitted owing a specific amount, and paid this amount to the creditor (in full settlement). Subsequent to establishing that the real purpose of the payment was to settle the whole dispute, the court in the Andy's Electrical case concluded that an offer of compromise was intended by the debtor. With reference to the Be Bop (SCA) case, it is difficult to accept that the debtor did not intend to settle the whole dispute and that its intention was that the rest of the claim should remain in issue. In addressing the disputed amount owing, the debtor refers to the latter of the two letters (dated 19 February 2002) sent to the creditor as a "final reconciliation". ${ }^{54}$ This reference is supplemented by the insertion of the words "full and final settlement of account" ${ }^{55}$ on the cheque payment which accompanied the said letter. The repetitive use of the word "final" (in the context of the content of both letters dated 19 February 2002 and the cheque payment) indicates that the debtor intends to bring finality to the whole dispute,

49 See eg, The Andy's Electrical case, par 343G-H; The Tractor case, 743A; The Van Breukelen case 19662 SA 285 (A) 290D; Kei Brick \& Tile v AM Construction 19961 SA 150 (E) 160A-B, (Minority Judgment); and see discussion in 2.2 above.

50 The Andy's Electrical case, par 343G-H.

51 Par 343H-344A.

52 Par 344C; see also Kei Brick \& Tile v AM Construction 19961 SA 150 (E) 161E-F, (Minority Judgment).

53 The Andy's Electrical case, at par 346A.

54 The Be Bop (SCA) case, at par 2, par 4, par 11; and see 3.2 above.

55 The Be Bop (SCA) case, at par 11. 
without intending that the rest of the claim remains in issue. ${ }^{56}$ Therefore, it is apt that the court in the Be Bop (CPD) case mentioned that the debtor considered its payment (in full and final settlement) to be made in favour of a "final balance". ${ }^{57}$ Hence it is difficult to accept the reasoning of the court in the Be Bop (CPD) case that no indications of a compromise were evident in the letters dated 19 February $2002 .^{58}$ That the debtor intended to compromise the claim and bring finality to the whole dispute is further supplemented by the fact that the debtor was willing to forfeit a claim for loss of profits for the late delivery of certain goods (by the creditor), which claim subsequently proved to be successful. ${ }^{59}$ The decision of the court in the Be Bop (SCA) case was therefore correct. $^{60}$ The Tractor case also serves as a justification for the decision in the Be Bop (SCA) case. ${ }^{61}$

In the Be Bop (SCA) case, when the creditor advised the debtor (in its letter dated 1 March 2002) that payment was not accepted in full and final settlement, ${ }^{62}$ the debtor responded by advising the creditor that the depositing of the cheque gave effect to the condition that the creditor accepted the

56 See also Cecil Jacobs v Mcleod \& Sons 19664 SA 41 (N) at 48E-G, where the use of the words, "in order to reach finality" is interpreted to bring an end to the dispute, if the creditor chooses to retain the amount delivered by the debtor.

57 Par 9.

58 Par 44.

59 See par 11 in the Be Bop (CPD) case, where the effect of the debtor's letter (dated 4 March 2002) addressed to the creditor is that if finality is not reached with the debtor's payment (to settle the whole dispute), a counterclaim will be pursued by the debtor for loss of profits for late delivery costs. The inference is that the counterclaim will be forfeited if finality is reached with the debtor's payment. This was not a bogus counterclaim as the debtor was successful with this counterclaim in the court a quo, after the court a quo found that an agreement of compromise did not exist (see par 1 and par 4 in the Be Bop (CPD) case). This successful counterclaim in the court a quo was not appealed by the creditor in the CPD (see par 1 and par 4 in the Be Bop (CPD) case). It was therefore a sound claim that the debtor was willing to forfeit, thereby indicating an inclination towards compromising the creditor's claim.

60 See par 11, where the SCA reasons that an offer of compromise was intended by the debtor.

61 In the Tractor case (at 743C) the court concluded that an offer of compromise existed, after reasoning that the debtor placed the disputed amounts in issue in the context of intending to discharge his entire liability in full and final settlement. Similarly in the Be Bop (SCA) case the debtor placed the disputed amounts in issue (in both its letters dated 19 February 2002) with the intention to discharge its entire liability, by sending the said letters and the cheque in full and final settlement to the creditor. Par 5. 
payment as full and final settlement of the claim. ${ }^{63}$ Whilst the said advice by the debtor was given to the creditor soon after the delivery of the cheque payment, it is nevertheless relevant to assist in establishing the intention of the debtor. This submission is made as it was reasoned (by the court) in the Harris case that such advice (which is made after delivery of the payment) on the part of the debtor would have "meant that the payment was in full settlement of the plaintiff's claim", ${ }^{64}$ thereby favouring the existence of an offer of compromise.

To support its finding that an offer of compromise was not intended by the debtor, the court in the Be Bop (CPD) case emphasised that if the debtor was serious about compromising the claim, it would not have attempted to stop payment on the cheque. ${ }^{65}$ However, in the Be Bop (SCA) case the court appropriately reasoned that this attempt by the debtor had no bearing on the fact that the cheque and the two letters addressed to the creditor (dated 19 February 2002) objectively constituted an intended offer of compromise. ${ }^{66}$ This reasoning is sound as the debtor was prompted to enquire about the countermanding of the cheque only once it received the creditor's letter (dated 1 March 2002). Had the creditor not sent this letter, the debtor would have had no reason to make any enquiries about a stop payment on the cheque. Therefore this evidence (that is, the debtor's attempting to stop payment on the cheque) does not appear to be relevant to the debtor's intention at the time he issued the cheque in favour of the creditor (in full and final settlement). On the contrary, if the debtor had not attempted to stop payment on the cheque, even if it had been possible to do so, it could have been argued in favour of the creditor that no attempt to stop payment was forthcoming by the debtor, because the debtor truly believed that it was solely/merely making payment towards an admitted liability. Contrary to the finding of the CPD, the court in the Be Bop (SCA) case was correct in that its interpretation was not unfavourable to the debtor for attempting to stop payment on the cheque.

63 Par 6.

64 At 657.

65 Par 47.

66 Par 12. 
Finally, Zeffertt notes that for an offer of compromise to exist "the proposal, objectively construed, must be intended to create binding legal relations and must have so appeared to the offeree". ${ }^{67}$ This reasoning was endorsed in both the Be Bop (CPD) case $^{68}$ and the Be Bop (SCA) case. ${ }^{69}$ An essential part of Zeffertt's reasoning is that it must appear to the creditor that an offer of compromise is intended. ${ }^{70}$ In this context, from the delivery of the cheque and the two letters dated 19 February 2002, the issue is whether or not, objectively construed, it appeared to the creditor that the debtor intended an offer of compromise. The court in the Be Bop (SCA) case correctly ruled that the creditor understood these three documents to constitute an intended offer of compromise. ${ }^{71}$ This ruling is justified as the creditor (in its letter dated 1 March 2002) repeatedly advised the debtor that it did not accept the payment in full and final settlement. The only plausible reason for the creditor's repeatedly emphasising this point in the same letter is that the creditor understood that the debtor wanted to bring finality to the entire dispute by intending to compromise the claim. The debtor therefore intended an offer of compromise and the same intention was conveyed to the mind of the creditor. ${ }^{72}$

In the light of the above submissions the court in the Be Bop (SCA) case correctly overruled the CPD, when the former held that an offer of compromise existed. In the Be Bop (CPD) case the court adopted a literal approach to the enquiry it formulated, ${ }^{73}$ and once it was established that the debtors' payment was consistent with the full extent of its admitted liability, the CPD easily ${ }^{74}$ concluded that the seller had made payment towards what it believed it was

67 Zeffertt, supra n 6, 38.

68 Par 27.

69 Par 10.

70 See also Christie, supra n 5, 457, where the author reasons "that if the debtor cannot prove that the creditor ought reasonably to have interpreted the letter and cheque as an offer of compromise", the contra proferentem rule should apply and the creditor can then retain and deposit the payment and sue for the balance outstanding.

71 Par 12; see also RCG Trade \& Finance $v$ Garstang 2002 JDR 0451 (W) 25, where it is explained that the creditor's attorney understood a crucial letter from the debtor, accompanied with the cheque, as an offer of compromise.

72 See also eg, Cecil Jacobs v Mcleod \& Sons 19664 SA 41 (N), at 48D-E.

73 See par 42, the enquiry formulated being "whether the offer to pay is intended as an offer of compromise or as an offer to pay what the debtor believes he owes the creditor".

74 The "ease" with which the CPD reached its finding is also supplemented by the use of the word "simply" in the last sentence at par 45. 
owing to the creditor. ${ }^{75}$ As a result the CPD found that payment had been made towards an admitted liability as opposed to an offer of compromise. The approach of the CPD appears to be consistent with the reasoning adopted in the Karson case, that it is easier to conclude that payment was made towards an admitted liability when the debtor delivers the precise payment he believes he owes to the creditor. ${ }^{76}$ It is respectfully reiterated that such a conclusion is not always easy to reach. ${ }^{77}$ Therefore criticism is hereby respectfully directed at the court in the Be Bop (CPD) case, because the evidence was overwhelming that an offer of compromise existed, yet it came to a different finding. On the contrary, the court in the Be Bop (SCA) case justifiably concluded that an offer of compromise existed.

In the Karson case, in order to establish if the debtor intended to compromise the creditor's claim the court had to determine whether the debtor included the interest amount (claimed by the creditor) in the offer that was presented to the creditor. ${ }^{78}$ Although the debtor made it expressly clear that the offer presented (in full and final settlement) was for 'all' amounts due and owing for the purchase of the property (save for the transfer costs), ${ }^{79}$ the court did not accept that the interest amount was included in the debtor's offer. Therefore the court concluded that an offer of compromise was not intended by the debtor. ${ }^{80}$ It is difficult to accept that the debtor's cheque payment was made with the intention that the interest amount claimed by the creditor was not included, and remained in issue. ${ }^{81}$ On the contrary, the probabilities favour a finding that the debtor intended to settle the entire claim by paying a particular amount, ${ }^{82}$ as the offer was made in full and final settlement for all amounts due and owing for the

75 Par 44-45.

76 Par 895G-H.

77 See the Andy's Electrical case, (at 344B-C) and the Tractor case, where the debtor delivered the amount it believed it owed the creditor, yet (in both cases) the court held that an offer of compromise existed. See also the Van Breukelen case, at 290D; and Harris $v$ Pieters 1920 AD 644, at 649 where the court envisages that an offer of compromise could exist even when "liability to the extent of the tender is admitted".

78 See par 890B.

79 See par 891B-C.

80 See par 896A-F.

81 See the Andy's Electrical case, at 344C for the approach of attempting to establish if the debtor intends an offer of compromise. Ibid. 
purchase of the property. Furthermore, this submission is justified as the debtor's offer in the Karson case was in response to the creditor's claim for both the interest and capital amounts owing. ${ }^{83}$ The use of the word "all" accompanied by the fact that the debtor made it expressly clear that the only amount excluded from the offer was the transfer costs means that the interest amount claimed was intended to be included by the debtor in his offer. ${ }^{84}$

The court in both the Karson case and the Be Bop (CPD) case appeared to have adopted a dismissive approach against the debtor (by too easily finding that no offer of compromise existed) when the debtor paid the precise amount he/it believed was owing to the creditor. Such an approach is in conflict with the approach taken in the Tractor case ${ }^{85}$ and the Andy's Electrical case, ${ }^{86}$ which clearly gives recognition and due application to the principle that such conduct by a debtor does not preclude the probability that an offer of compromise could nevertheless still be accompanied by the precise admission of liability. The approach adopted by the latter two jurisdictions and now the SCA, in the Be Bop (SCA) case, is certainly correct and consistent with the reasoning of the

83 See par $890 \mathrm{H}-891 \mathrm{C}$.

84 See par 891B-C, where the debtor's letter evidences that the offer was for all amounts due and owing and the only amount specifically excluded from the offer (relating to the purchase of the property) is the transfer costs. This said letter was sent to the creditor in response to the creditor's letter (at par $890 \mathrm{H}-\mathrm{I}$ ) advising the debtor that an interest amount was due in addition to the capital amount. The creditor considered the interest amount to be "due" (par $890 \mathrm{H}$ ), and the debtor (in response thereto) couched its offer to include "all" amounts that were considered "due and owing" (par 891B-C). The only amount excluded from the offer was the transfer costs, therefore the interest amount was considered and covered in the offer that was presented by the debtor to the creditor. In this context an offer of compromise is clearly made. See eg, in the Van Breukelen case, at 290D-E, where the Appellate Division reasoned that a compromise was made evidently clearer from the statement that the offer was made for "any" amount which might be found to be due, relating to the dissolution of the partnership; and RCG Trade and Finance $v$ Garstang 2002 JDR 0451 (W) at 24, where the court considers the use of the words "all claims" (by the debtor when he sought to settle the debt) to be crucial when it concluded that an offer of compromise was intended, "and not merely the evidence of an intention to pay".

85 See par 743A-E.

86 See par 343F-344C, especially where Didcott J bluntly criticises judgments that simplistically distinguish "offers of compromise from payments of admitted debts, as if the one sort of transaction necessarily excluded the other". In the Karson case and the Be Bop (CPD) case, by easily finding that an offer of compromise did not exist, it appears (based on the facts) that once the court in both cases found that payment was made towards an admitted debt, it failed to consider if the said payment of the admitted debt was accompanied by an offer of compromise (see at par 344B-C, the comment relating to Zeffertt). This submission is made as it has been argued in this discussion that an offer of compromise existed in both the Karson case and the Be Bop (CPD) case. 
Appellate Division ${ }^{87}$ in the Van Breukelen case, ${ }^{88}$ that admission (by the debtor) of an amount due to the creditor is not decisive that an offer of compromise is excluded.

\section{$5 \quad$ Acceptance of offer}

To consider whether or not acceptance has been established it is assumed that an offer of compromise exists. Otherwise it is not necessary to proceed with the ‘acceptance' enquiry.

In the Be Bop (CPD) case, after receiving the cheque the creditor made it expressly clear to the debtor (in writing), that it unequivocally rejected the cheque as payment for the full and final settlement of the creditor's claim, and invited the debtor (if it disagreed with this stance) to stop payment on the cheque. $^{89}$ The court in the Be Bop (CPD) case held that this conduct was not compatible with acceptance of an offer of compromise. ${ }^{90}$ Acceptance of an offer must usually be clear and unequivocal/unambiguous such that a reasonable person would interpret it as an acceptance. ${ }^{91}$

Since the creditor in the Be Bop (SCA) case appeared to have rejected the offer in writing, ${ }^{92}$ prima facie it seems that the parties were not ad idem. Therefore no contractual obligations would automatically arise. However, consideration must be given as to whether or not the act of retention of the monies might constitute an acceptance by conduct. ${ }^{93}$ Furthermore, it is trite that

87 Hereafter the AD.

88 See par 290D; Also see Harris v Pieters 1920 AD 644, at 648-649.

89 Par 10.

90 Par 46.

91 See eg, Boerne v Harris 19491 SA 793 (A); Van Jaarsveld v Ackerman 19752 SA 753 (A); Kahn v Raatz 19764 SA 543 (A); Christie, supra n 5, 60-62; and Sharrock, supra n 5, 62.

92 See par 5, where the creditor reiterates that the payment is not accepted in full and final settlement of the account.

93 See eg, Zeffertt, supra n 6, 38. 
the offeror can impliedly ${ }^{94}$ or expressly ${ }^{95}$ indicate the method of acceptance (which includes relieving the offeree from communicating his acceptance), ${ }^{96}$ and where the interpretative effect of the offer is that the payment may be retained only upon acceptance of the condition that the debtor's whole liability is discharged, then retention of the monies will generally constitute acceptance of the offer of compromise. ${ }^{97}$ The same consequence follows if a reasonable person in the circumstances would interpret the retention of the payment to signify acceptance. ${ }^{98}$ These principles are justifiably applicable, as a creditor who expressly rejects an offer of compromise must as a natural consequence return the debtor's payment. ${ }^{99}$ It is therefore understandable that the retention and/or appropriation and/or depositing of the debtor's payment, accompanied with an express rejection of the offer of compromise, (on the part of the creditor) generally ${ }^{100}$ constitutes acceptance of the offer of compromise. ${ }^{101}$ This logically follows, as the "creditor is not allowed to approbate and reprobate at the same time". ${ }^{102}$ However, it should be noted (and it has already been discussed) ${ }^{103}$ that if an offer of compromise is not established, the creditor can retain the payment and sue for the balance owing by the debtor.

In the Be Bop (SCA) case, the issue is whether the retention (depositing and subsequent partial appropriation) of the debtor's cheque payment constitutes acceptance of the offer, (which would be consistent with the general

94 Cecil Jacobs v Mcleod \& Sons 19664 SA 41(N) 48D-E; and Malan and Pretorius Bills of Exchange 327.

95 The Van Breukelen case, at 289; Blumberg v Atkinson 19744 SA 551 (T) 554; Malan and Pretorius, supra n 94, 327.

96 Cecil Jacobs v Mcleod \& Sons 19664 SA 41(N) 50H-51A; Christie, supra n 5, 457; and Zeffertt, supra $\mathrm{n}$ 6, 38-39.

97 Cecil Jacobs v Mcleod \& Sons 19664 SA 41(N) 50H-51A.

98 See eg, Zeffertt, supra n 6, 38.

99 See eg, Harris v Pieters 1920 AD 644, 650; Neville v Plasket 1935 TPD 115, 120; Turgin v Atlantic Clothing Manufacturers 19543 SA 527 (T) 533; and Blumberg v Atkinson 19744 SA 551 (T) 553H-554A.

100 See McLennan, supra n 13, 686, where the author explains that this is not an absolute rule that provides conclusive proof of acceptance of the offer.

101 See eg, Neville v Plasket 1935 TPD 115, 120; Turgin v Atlantic Clothing Manufacturers 19543 SA 527 (T) 532G-H; the Van Breukelen case, 288A and 290H; the Tractor case; Cecil Jacobs v Mcleod \& Sons 19664 SA 41(N) 48H-51A; the Andy's Electrical case, 343A-C; Kei Brick \& Tile v AM Construction 19961 SA 150 (E) 152I-153B; and Absa Bank $v$ Van De Vyver 20024 SA 397 (SCA) 402B-F.

102 Turgin v Atlantic Clothing Manufacturers 19543 SA 527 (T) 532.

103 See discussion under par 2.1 above. 
interpretation of our judiciary), or whether the circumstances justify a deviation from the general interpretation. The case of Burt $v$ National Bank of South Africa $L t d^{104}$ serves as a deviation from the general interpretation, ${ }^{105}$ because the creditor (after rejecting the offer) returned the debtor's money (with it's own cheque), which the debtor rejected. Thereafter the creditor placed the funds in a trust account for the benefit of the debtor to request at any time. In the $B e$ Bop (SCA) case the creditor did not return the cheque payment and whilst the money was placed in a trust account (of the creditor's attorneys) it was clearly not available at the debtor's disposal to request it at any time. ${ }^{106}$ Instead, at some point a portion of these funds were appropriated for the benefit of the creditor. ${ }^{107}$ Therefore, the circumstances in this case did not justify a deviation from the general interpretation of our judiciary.

104 Burt v National Bank of South Africa 1921 AD 59 65-66.

105 For a deviation from the general interpretation, see also eg, Patterson Exhibitions $v$ Knights Advertising \& Marketing 19913 SA 397 (A), where the debtor made an offer of compromise, which included payment in the form of a current cheque and five post-dated cheques. The creditor deposited the current cheque and expressly rejected the offer of compromise. Despite the creditor's depositing the current cheque and retaining the postdated cheques, the court held that the offer of compromise was rejected, and that an agreement of compromise was therefore not concluded. This is not applicable to the $B e$ Bop (SCA) case, as it was reasoned by the SCA in the Absa Bank case (at par 9), that the Patterson Exhibitions v Knights Advertising \& Marketing 19913 SA 397 (A) case is not applicable where "there was a simple offer of one cheque the proceeds of which were retained". For a view rejecting the decision in Patterson Exhibitions v Knights Advertising \& Marketing 19913 SA 397 (AD), see RCG Trade \& Finance v Garstang 2002 JDR 0451 (W) at 27-30. Without commenting on the merits of the judgment in the former case, it is accepted, based on the doctrine of judicial precedent (see the Absa Bank case at par 9), that this judgment is not applicable to the Be Bop (SCA) case; See also McLennan, supra $\mathrm{n} 13,686-689$, wherein it is argued that the Absa Bank case should have been viewed as a deviation from the usual interpretation, as the author argues that the banking of the cheque did not constitute proof of acceptance of the debtor's offer of compromise. See also Steenkamp v Union Government 19471 SA 449 (C) and Blackie Swart Argitekte v Van Heerden 19861 SA 249 (A), where it was held in the former case that the employee of the creditor, who had deposited the cheque payment, did not have authority to compromise the claim, and in the latter case, the court held that the creditor's attorney or the creditor's attorney's secretary (who deposited the cheque payment) did not have authority to compromise the creditor's claim. Therefore in both cases it was held that the offer of compromise was not accepted. In the Be Bop (SCA) case (at par 14, referring to $\mathrm{n}$ 13 in that judgment), it was reasoned that it was not necessary to decide if the employee of the creditor who deposited the cheque payment, lacked authority to compromise the creditor's claim, as it was not raised as an issue of contention before the SCA. However, if this issue had been raised it would probably have been addressed in the light of the principles relating to estoppel.

106 See par 5 and par 14.

107 Par 2 and par 14. 
Furthermore, the $A D$ has made it categorically clear that when an offer of compromise is rejected the creditor is obliged to return the debtor's payment and the debtor's legal position is not affected if he fails to request the return of the payment. ${ }^{108}$ At times our judiciary has held that the retention of the monetary payment (from the debtor) without any offer to return it must be held to constitute acceptance of the offer of compromise. ${ }^{109}$

The court in the Be Bop (SCA) case therefore reached the correct finding that the depositing, retention and subsequent appropriation of a portion of the debtor's payment in favour of the creditor concluded an agreement of compromise between both parties. However, the method utilised to reach its finding invites further discussion.

In reaching this finding the court reasoned that although actual consensus may have been lacking between the parties, the debtor's belief was reasonable that the creditor was accepting the offer of compromise. ${ }^{110}$ In this context, the court in the Be Bop (SCA) case utilised the reliance theory to justify its finding. In terms of this theory, even if a person (A) does not intend to be bound by a contract, he $(A)$ will be bound by that contract if he, by his conduct or words, led the other contracting person $(B)$, reasonably to believe that he $(A)$ intended to be bound by the contract and the terms contained therein. ${ }^{111}$

In the context of the reliance theory, the issue in the Be Bop (SCA) case is whether the debtor's belief was reasonable that the creditor accepted the offer of compromise. The SCA held that the debtor's belief was reasonable, and therefore that an agreement of compromise was concluded. The issue that arises is to question whether or not the debtor's belief was reasonable (that the creditor accepted it's offer of compromise), as the creditor (in it's letter dated 1

108 Patterson Exhibitions v Knights Advertising \& Marketing 19913 SA 397 (A) 528G-H.

109 See eg, Neville $v$ Plasket 1935 TPD 115, 120; and Turgin $v$ Atlantic Clothing Manufacturers 19543 SA 527 (T) 533. However, exceptions do apply (see n 104 and n 105 in general).

110 See the Be Bop (SCA) case, at par 14.

111 See eg, Sonap Petroleum (SA) v Pappadogianis 19923 SA 234 (A); Steyn v LSA Motors 19941 SA 49 (A); and Constantia Insurance $v$ Compusource 20054 SA 345 (SCA). 
March 2002) repeatedly advised the debtor that it's payment was not accepted in full and final settlement and it invited the debtor to stop payment on the cheque if the debtor disagreed with the creditor's stance. ${ }^{112}$ The debtor was further advised by the creditor's attorneys (in its letter dated 7 March 2002) that it would place the money received in its trust account and issue summons for the full amount owing. ${ }^{113}$ Notwithstanding these facts, it appears that the depositing, retention and subsequent partial appropriation of the proceeds from the payment persuaded the SCA to find that such conduct on the part of the creditor led the debtor to reasonably believe that an agreement of compromise was concluded. ${ }^{114}$ However, Sharrock reasons that the reliance theory will not be applicable, where the party wishing to assert the contract is exposed to the possibility that more than one reasonable conclusion exists and it is not possible for the court to favour either of the conclusions as the more reasonable. ${ }^{115}$ In other words, if it can be reasonably inferred on the one hand that the creditor expressly rejects the offer of compromise, whilst on the other hand it can also be reasonably inferred from the depositing, retention and appropriation of the proceeds from the cheque that the creditor accepts the offer of compromise, then the debtor may not necessarily hold the creditor to the latter interpretation, if the creditor intends the former interpretation. ${ }^{116}$ In this context, in the Be Bop (SCA) case the creditor's express rejection of the offer of compromise (and its invitation to the debtor to stop payment on the cheque, accompanied by the warning of it's intended course to issue summons for the whole amount owing) potentially creates more than one reasonable interpretation which the debtor was exposed to. Use of the reliance theory therefore becomes contentious. Unfortunately, the SCA did not address this issue directly and it is therefore respectfully submitted that it will be necessary for our judiciary to do so in the future so that principles are established when

\section{Par 5.}

113 Par 7.

114 See par 14. In deciding whether or not the debtor's belief was reasonable, it should also be noted that the debtor responded to what the SCA referred to as the creditor's purported rejection, and advised the creditor (in the letter dated 4 March 2002) that the debtor understood the creditor's action of depositing the cheque on 28 February 2002 to constitute acceptance of the condition that payment was made in full and final settlement (see par 6).

115 Sharrock, supra n 5, 77.

116 See eg, Diamond v Kernick 19473 SA 69 (A). 
applying the reliance theory to establish if an agreement of compromise has been concluded.

If the applicability of the reliance theory is questionable in the Be Bop (SCA) case, was there a more appropriate approach available to assist the SCA to reach a finding that is consistent with the general interpretation of our judiciary in the past ? $^{117}$ This question may be answered in the affirmative. It has already been explained that the debtor has the right to determine the mode of acceptance (which includes relieving the creditor from communicating its acceptance). ${ }^{118}$ In this case the SCA (by its own interpretation of the facts) justifiably found that the cheque, together with both of the letters addressed by the debtor to the creditor, "formed part of the offer and amounts to an invitation to deposit the cheque to indicate its acceptance". ${ }^{119}$ The creditor was therefore relieved of communicating its acceptance, and the depositing of the cheque (into the creditor's bank account) complied with the mode of acceptance impliedly indicated by the debtor. ${ }^{120}$ In this context, any conditions attached to the acceptance (like the creditor's purported rejection of the offer of compromise in its letter dated 1 March 2002) are irrelevant and unenforceable, ${ }^{121}$ and the subsequent partial appropriation of the proceeds from the cheque confirms the creditor's acceptance.

\section{Conclusion}

The court in the Be Bop (SCA) case came to the correct finding that an offer of compromise existed. Whilst the judgment is brief, the finding itself gives

117 In this context the general interpretation of our judiciary would favour a finding that the creditor's depositing, retention and subsequent partial appropriation of the proceeds from the cheque payment constitutes acceptance of the offer of compromise. See eg all the references in $n 101$.

118 See references in $\mathrm{n} 94, \mathrm{n} 95$ and $\mathrm{n} 96$.

119 See the Be Bop (SCA) case, at par 12.

120 See eg, Cecil Jacobs v Mcleod \& Sons 19664 SA 41(N) at par 48D-E and par 50H-51A; and Malan and Pretorius, supra n 94, 327.

121 See eg, the references in $\mathrm{n} 13$ and $\mathrm{n}$ 14. Also note that the court in the Be Bop (SCA) case refers to the creditor's letter (dated 1 March 2002) as a purported (at par 2 and par 12) rejection of the debtor's offer. 
practical recognition to the principle that admission of liability for a specific amount, accompanied by payment (in full and final settlement), may still be accompanied by an intended offer of compromise, instead of merely making payment towards an admission of liability.

Given that the trial court and the full bench of the CPD came to an incorrect finding, our judiciary should in future be more cautious in their approach to disputes of this nature. Our judiciary should approach these disputes (in the specific context that this case discussion alludes to) from the premise that payment of an admitted debt for a specific amount can be accompanied by an offer of compromise. ${ }^{122}$ This approach should respectfully be preferred over the approach alluded to in the Karson case, wherein the court addressed the issue from the premise that it is easier to reach a conclusion that payment towards an admitted liability is intended where the payment made is consistent with the precise amount the debtor believes he owes the creditor. ${ }^{123}$ The court in the Be Bop (CPD) case appeared to have adopted the approach taken in the Karson case. This submission is made as it is difficult to understand how the CPD easily $^{124}$ came to the incorrect finding when the facts clearly indicated that an offer of compromise existed. However, the concern remains whether this ruling of the $\mathrm{SCA}^{125}$ will in future assist our judiciary in their approach to disputes of this nature, or whether the pattern of interpretative inconsistency will continue.

Finally, on the issue of whether or not acceptance of the offer of compromise was established in the Be Bop (SCA) case, it appears that the depositing of the cheque into the creditor's account was sufficient to constitute acceptance of the

122 See eg, the Andy's Electrical case, at 343F-344C; the Tractor case, at 743A; the Van Breukelen case, at par 290D; and Cecil Jacobs v Mcleod \& Sons 19664 SA 41(N), at $46 \mathrm{C}-\mathrm{D}$, where Kenedy $\mathrm{J}$ (in the context of payments made in full settlement) reasons that the premise should be that an offer of compromise exists, where liability to the extent of the tender has been admitted, and this reasoning should only change if the evidence or surrounding circumstances indicates the contrary.

123 See the Karson case, at par 895G-H.

124 In this regard consider the use of the word "simply" at par 45, in the Be Bop (CPD) case, and also see (at par 44 and par 45) how the said court easily reaches the incorrect finding, once it was established that the debtor's payment was consistent with its admitted indebtedness.

125 The Be Bop (SCA) case. 
offer of compromise, as it was necessarily implied that the depositing of the cheque will constitute acceptance of the offer of compromise. ${ }^{126}$ The subsequent partial appropriation of the proceeds from the cheque confirms such acceptance. This line of reasoning is consistent with the general interpretation favoured by our judiciary in the past. ${ }^{127}$ However, in this case, the SCA sought to introduce the reliance theory as a basis to find that an agreement of compromise was concluded. As argued above, introducing the reliance theory into this arena (relating to whether an agreement of compromise is concluded) has its difficulties. Whether these difficulties are insurmountable or not will have to be addressed by our judiciary on a case by case basis. This submission is made so that principles may be established to reconcile how a debtor's belief that the creditor has accepted his offer of compromise is reasonable, when the creditor expressly iterates to the debtor that the offer is not accepted in full and final settlement. Regarding the acceptance issue, where the content of the creditor's correspondence to the debtor is ambiguous in that the creditor stipulates that he has deposited and appropriated the proceeds of the debtor's payment, but that he does not accept the payment in full and final settlement, consideration may be given in the future to the applicability of the contra proferentem rule to be interpreted against the creditor.

126 See the Be Bop (SCA) case, at par 12. Also see eg, Cecil Jacobs v Mcleod \& Sons 19664 SA 41(N), at par 48D-E and par 50H-51A; and Malan and Pretorius, supra n 94, 327.

127 See eg, Cecil Jacobs v Mcleod \& Sons 19664 SA 41(N), at par 48D-E and par 50H-51A; and see all the references in $\mathrm{n} 101$. 


\section{Bibliography}

Christie Law of Contract

Christie RH The Law of Contract $5^{\text {th }}$ ed (Butterworths Durban 2006)

Kerr Principles of Law of Contract

Kerr AJ The Principles of the Law of Contract $6^{\text {th }}$ ed (Butterworths Durban 2002)

Malan and Pretorius Bills of Exchange

Malan FR, Pretorius JT and Du Toit SF Malan on Bills of Exchange,

Cheques and Promissory Notes $4^{\text {th }}$ ed (Butterworths Durban 2002)

McLennan 2002 SALJ

McLennan JS “Acceptance of Offers of Compromise - 'In Full Settlement"” 2002119 South African Law Journal 686-689

Sharrock Business Transactions Law

Sharrock R Business Transactions Law $7^{\text {th }}$ ed (Juta Cape Town 2007)

\section{Zeffertt 1972 SALJ}

Zeffertt D "Payments 'In Full Settlement" 197289 South African Law

Journal 35-48

\section{Register of cases}

Absa Bank Ltd v Van De Vyver NO 20024 SA 397 (SCA)

Andy's Electrical v Laurie Sykes (Pty) Ltd 19793 SA 341 (N)

Be Bop A Lula Manufacturing \& Printing CC v Kingtex Marketing (Pty) Ltd 2008 3 SA 327 (SCA)

Be Bop A Lula Manufacturing \& Printing CC v Kingtex Marketing (Pty) Ltd 2006 6 SA $379(C)$

Bop A Lula Manufacturing \& Printing CC v Kingtex Marketing (Pty) Ltd [2007] SCA 162 (RSA)

Blackie Swart Argitekte v Van Heerden 19861 SA 238 (A) 
Blumberg v Atkinson 19744 SA 551 (T)

Burt NO v National Bank of South Africa Ltd 1921 AD 59

Cecil Jacobs (Pty) Ltd v Mcleod \& Sons Ltd 19664 SA 41 (N)

Constantia Insurance $v$ Compusource 20054 SA 345 (SCA)

Diamond v Kernick 19473 SA 69 (A)

Harris v Pieters 1920 AD 644

Louw v Granowsky 1960 (2) 637 (SWA)

Karson v Minister of Public Works 19961 SA 887 (E)

Kei Brick \& Tile Co (Pty) Ltd v AM Construction 19961 SA 150 (E)

Neville v Plasket 1935 TPD 115

Odendaal v Du Plessis 1918 AD 470

Patterson Exhibitions CC v Knights Advertising \& Marketing CC 19913 SA 397

(A)

RCG Trade \& Finance (Pty) Ltd v Garstang and Another 2002 JDR 0451 (W)

Sonap Petroleum (SA) v Pappadogianis 19923 SA 234 (A)

Steenkamp v Union Government 19471 SA 449 (C)

Steyn v LSA Motors 19941 SA 49 (A)

Tractor \& Excavator Spares (Pty) Ltd v Lucas J Botha (Pty) Ltd 19662 SA 740

Turgin v Atlantic Clothing Manufacturers 19543 SA 527 (T)

Van Breukelen en 'n Ander v Van Breukelen 19662 SA 285 (A)

\section{List of abbreviations}

AD Appellate Division

CPD Cape Provincial Division

eg for example

NPD Natal Provincial Division

par paragraph (s)

SCA Supreme Court of Appeal

TPD Transvaal Provincial Division 